\title{
"FRIENDS FROM AN EARLIER LIFE": RADICAL POSSIBILITIES OF NOSTALGIC MELANCHOLY IN POEMS OF THE 1947 INDIAN PARTITION
}

\author{
Anindya Raychaudhuri \\ University of St Andrews, UK
}

\begin{abstract}
This paper will examine poetic responses to the trauma of Partition, and will consider both poetry written at the time and since. I will examine works in Bengali, Urdu and English, by such poets as Agha Shahid Ali, Jibanananda Das, Faiz Ahmed Faiz, and Achintya Kumar Sengupta. I will examine how poets deal with the memory of the violence and the resulting legacy of dislocation and alienation. I will examine the possibilities of poetic melancholy as a tool in order to respond to and negotiate the enforced and violent change in identities that Partition precipitated. In the process, I will make a case for the radical potential of what might be called nostalgic melancholy. I argue that in these cases poetic melancholy can be read as a corrective to the imperialist act of Partition, as well as a gesture which defies the nationalist appropriation of history by the independent, postcolonial states. I will analyse how poets from both countries have tried, through their writing, to question the very legitimacy of the border that divides them.
\end{abstract}

Keywords: A. Ali, J. Das, F.A. Faiz, Melancholy, Partition, Poetry, A. Sengupta.

\section{RESUMEN}

Este artículo estudia la poesía sobre la Partición, tanto la contemporánea con los hechos como la que se ha generado después. Prestaré atención a poemas en bengalí, urdu e inglés, de autores como Agha Shahid Ali, Jibanananda Das, Faiz Ahmed Faiz y Achintya Kumar Sengupta, que hacen memoria de esa violencia, así como de su legado de desestructuración alienación. También estudiaré la melancolía poética como instrumento para responder y renegociar las identidades forzadas abocadas por la Partición. La melancolía poética puede leerse como una enmienda a la división de India como un hecho imperialista, que a la vez desafía la apropiación histórica que han hecho los estados poscoloniales de esa violencia. Así, poetas de ambos lados de la frontera han cuestionado la legitimidad de la frontera que los separa.

Palabras clave: A. Ali, J. Das, F.A. Faiz, melancolía, partición, poesía, A. Sengupta. 
Few events in the history of the Indian subcontinent have had as seismic an impact as Partition. Virtually every arena of public and private life of the subcontinent has been coloured by the events of Partition in ways too numerous to list. From the periodic wars the countries insist on fighting with each other, to communal riots and terrorist attacks to literary and cultural production -in all of these spheres the postcolonial nation-states and their people are still working through the trauma caused by the events of seven decades ago.

Even though the bare outlines of the events might be fairly well-known, it is perhaps still wise, especially when examining literary responses to such a traumatic event, to always turn first to history. As the British left India after two hundred years of official and unofficial colonial rule, ${ }^{1}$ the country was divided along religious lines, with Punjab in the west and Bengal in the east divided in two. the land and its people were divided into two new states, broadly along religious lines. West Punjab, along with Sindh, Baluchistan, North-West Frontier Province, together with East Bengal, formed the new state of Pakistan with a majority Muslim population. This was a state of two halves, separated by hundreds of miles of India, which had a Hindu majority.

In part the significance of Partition comes from the unprecedented levels of violence - estimates of actual numbers of casualties remain controversial. The most conservative figure of the number of deaths was that suggested by the eyewitness account of British administrator Penderel Moon (293) who, in 1961, wrote that he believed only about 200,000 people were killed in the Punjab. At the other end of the scale, Kavita Daiya is one of a number of South Asian scholars who has put the figure at 'at least two million' (6). Ian Talbot has argued that the number 'is conventionally reckoned at around 1,000,000', (420) though Gyanendra Pandey has questioned the basis for this acceptance on the grounds that 'it appears something of a median' (89). In short, the exact number will probably be never known. What is generally accepted is that along with the death toll, the Partition led to the largest forced migration in human history, with an estimated 18 million people forced to leave their homes forever (Talbot 420). In addition between 100,000 and 150,000 women were abducted, raped and often forced to convert (See Butalia 1998; Menon and Bhasin 1998). The emotional losses were also huge, as people had to leave ancestral homes - communities where they had been living since time immemorial. Most were unable to take any of their property with them; some deliberately chose to leave everything behind because they were convinced they could come back at a future date. Millions of people became destitute overnight. Returning home proved impossible, as conflict between the two states intensified, leading to multiple wars in the past seven decades.

1 The exact start date of British rule in India is contested and beyond the scope of this paper - technically it was acquired by the British State in 1858, though British rule through the East India Company had lasted for at least a hundred years prior to that. 
Given the scale of mass-suffering, it is not surprising that scholars have looked to psychoanalysis and trauma theory to model the way Partition gets narrated or silenced, the way it gets repressed and returns as a haunting. Scholars like Joe Cleary (2002), Jill Didur (2006), Ananya Jahanara Kabir (2005) and Ashish Nandy (foreword to Sengupta 2003), among others, have repeatedly returned to psychoanalysis. Here is Nandy, for example, analyzing the legacy of Partition in such terms, when he says that the trauma of Partition,

... haunt $[s]$ not only the victims and the perpetrators, but also the following generations, which inherit without as much as an exchange of a word on the subject, the fears, the anxieties, tensions ... [the] unexamined past has to be lived out over the succeeding generations. (Sengupta Ix)

It is this haunting presence of a past trauma that leads to, in the words of Terri Tomsky, 'melancholia [becoming] the affect that dominates Partition scholarship. (61)

Tomsky joins a long list of scholars looking to reclaim the radical possibilities inherent within the affect of melancholia, wanting, as she puts it, 'to break with the Freudian concept of 'good' mourning versus 'bad' melancholia to consider ... melancholia ... as a critical force' (Tomsky 64). Freud's famous distinction between mourning and melancholia has been referred to many times, but it might be worth returning to it briefly here. Freud defines mourning as the "the reaction to the loss of a beloved person or an abstraction taking the place of the person, such as fatherland, freedom, an ideal and so on.' (203) In their summary of Freud's ideas, David L. Eng and David Kazanjian write that, for Freud, 'mourning is a psychic process in which libido is withdrawn from a lost object. This withdrawal cannot be enacted at once. Instead, libido is detached bit by bit so that eventually the mourner is able to declare the object dead and to move on to invest in new objects'. (Eng and Kazanjian 3) Melancholia, on the other hand, is a pathological manifestation of mourning, typically,

characterised by a profoundly painful depression, a loss of interest in the outside world, the loss of the ability to love, the inhibition of any kind of performance and a reduction in the sense of self, expressed in self-recrimination and self directed insults, intensifying into the desultory expectation of punishment. (Freud 204)

In Eng and Kazanjian's words, 'Freud describes melancholia as an enduring devotion on the part of the ego to the lost object. A mourning without end, melancholia results from the inability to resolve the grief and ambivalence precipitated by the loss of the loved object, place or ideal.' (3)

Interestingly, however, as Eng and Kazanjian also point out, though Freud is careful to set up and police this distinction between normal and healthy mourning, and pathological melancholia, the reader gets the sense that he, Freud, is not quite comfortable with the simplicity of the distinction. 'The only reason, in fact, why [mourning] does not strike us as pathological is that we are so easily able to explain it.' (204) As Eng and Kazanjian put it, 'Were one to understand melancholia 
better, Freud implies, one would no longer insist on its pathological nature.' (Eng and Kazanjian 2003: 3)

Eng and Kazanjian suggest that 'a better understanding of melancholic attachments to loss might depathologize those attachments, making visible not only their social bases but also their creative, unpredictable, political aspects.' A melancholic attachment to past trauma, then, can provide a way of leading to Walter Benjamin's conceptualization of historical materialism which is, he argues,

... a process of empathy whose origin is the indolence of the heart, acedia, which despairs of grasping and holding the genuine historical image as it flares up briefly. Among Medieval theologians it was regarded as the root cause of sadness ... empathy with the victor invariably benefits the rulers ... A historical materialist therefore dissociates himself from it as far as possible. He regards it as his task to brush history against the grain. (Benjamin 247-248)

In other words, and following Benjamin, Eng and Kazanjian suggest that a melancholic reading of history might represent 'an ongoing and open relationship with the past' leading to different ways of 'rewriting the past as well as reimagining the future'. (5)

Ranjana Khanna, in her study Dark Continents: Psychoanalysis and Colonialism makes a similar intervention when she 'reformulates melancholia as an ambivalent dynamic of loss and critical agency'. (Tomsky 69) Elsewhere, Khanna has argued that the affect of melancholia 'implicitly provides ... an ethico-political gesture toward the future' because 'the melancholic's critical agency, and the peculiar temporality that drags it back and forth at the same time, acts toward the future'. (Khanna 2006) For Khanna, this affect of melancholia is a fundamental part of postcolonial theory itself:

this temporal shift is particularly evident in studies of colonial and postcolonial subjectivities in relation to spatiality ... Melancholia is endemic to the field of postcolonial studies, and has always been the driving force behind it, because it is not only recently that lament, the elegiac, and the melancholic response have been constitutive of the field ... [T] here has also been an affect of melancholia in play that involves a relationship to loss and death of something somewhat difficult to locate, resulting in a critical agency distinct from overt self-critical rejection. (Khanna 2006)

It is in this context that I wish to study poetic responses to the Indian partition. It is my contention that this body of literature can be read as a defiantly melancholic attachment to the history of Partition, which works as an explicit or implicit challenge both to the colonialist-imperialist project of Partition in the first place, and to the way this history has been appropriated by the nation and state building process of all three of the postcolonial nation-states.

It is slightly surprising that more attention has not been paid to the poetry of Partition. As Tomsky has argued, most of the scholarship on Partition literature 'concentrate[s] on novels and short stories in ... discussions of collective cultural memories' (65) Separately, Kabir has also called for the need 'to move beyond the 
scholarly preoccupation with narrative modes of remembering Partition'. (15) In this chapter, I hope to begin to demonstrate the important role played by poetry in the cultural afterlives of Partition. It is my contention that this role is particularly important when examining the radical nature posed by the affect of melancholia because so many of the poets I am examining are using forms of nostalgic melancholy in order to construct alternative, oppositional readings of history.

The body of poetry I am studying represents work from four different communities which were most directly affected by the events of Partition - Bengali, Kashmiri, Punjabi and Sindhi, as well as the three major religions- Hinduism, Islam and Sikhism. In many cases the poets themselves became refugees and used their work as an elegy for the lost homeland. The poems represent a particularly radical, critical engagement with history, through which, in Tomsky's words, melancholia 'does not stultify but actually energises, becoming the agent for remedial anti-state activity.' (69) The poetry represents at least five different linguistic and poetical traditions: Bengali, Punjabi, Sindhi, Urdu and, inevitably, English. In my study, I have used established, published translations where possible — where such translations do not exist, I have provided my own.

Given the exilic background of many of these poets, it is not surprising that the poetry often exist in the margins, capturing the moment of transience as the East/West border is being crossed. Here, for example, are the opening lines of Bengali poet Achintya Kumar Sengupta's poem titled 'Refugee':

Come on, quickly,

No more waiting - we have to leave now

No point giving in to the

Dreamy delightful sleep of the dawn

We have to get up, there is no time

This chance will not come again

...

The small boy with sleep-filled eyes asks,

'Where are we going from there?'

'Where? To our new home.' (Sengupta 9)

It is no accident that the journey starts at dawn. One of commonest images of the birth of the country used at the time and since is that of the dawn of a new day. Midnight, as the moment of the birth of a new day, and dawn, as the moment of a new sunrise, have both been used as powerful symbols of independence. Famously, the first Indian Prime Minister Jawaharlal Nehru referred to this image in his inauguration speech:

At the stroke of the midnight hour, when the world sleeps, India will awake to life and freedom. A moment comes, which comes but rarely in history, when we step out from the old to the new, when an age ends, and when the soul of a nation, long suppressed, finds utterance ... At the dawn of history, India started on her unending quest, and trackless centuries are filled with her striving and grandeur of her success and failures. (Nehru 25) 
One of the ways in which the body of poetry I am studying poses a radical challenge to the state-building process is by appropriating the image of the start of a new age not in order to reinforce the state-endorsed narrative, but to highlight the melancholia, the suffering of the marginalized and displaced. Punjabi poet Amrita Pritam provides a perfect example in her poem 'At Midnight':

Your memory knocks at my door.

These are not words of song

But drops of sweat on love's brow.

These are not words of song

They are tears that choke my pen.

These are not words of song

Wounded silence weeps. (Pritam 21)

If the official nationalist hagiographers were celebrating the birth of the nation, the poets were, often, deliberately using birth-related imagery to undermine the triumphant nationalism which was, for them, entirely inappropriate to the trauma of Partition. In "The Scar of a Wound," Pritam powerfully re-writes the mythology of the birth of a nation:

When they forced my mother's womb

I came as every child must come;

I am the mark of that blow,

Violation bade me grow;

In my country's agony

They seared my mother's brow with me

When they forced my mother's womb. (Pritam 97)

Far from Partition being the 'birth-pangs' of the new nations, as is discussed ad nauseum in numerous newspaper articles and school textbooks, it is the source of the trauma that results in the deformation of the nation that is being born. The nation is 'the scar of that wound/That in my mother's body burned' - Pritam uses words such as 'curse' (revealingly and wonderfully rhymed with 'nurse'), 'agony', 'stench', 'loathsomeness' and 'torment' (Pritam 97-98) to reinforce the notion that the birth of the nation was no natural act, but a violent and horrific act of the child being 'forced' from the 'mother's womb'.

Faiz Ahmed Faiz, an Urdu poet originally from Kashmir, who moved to Pakistan after Partition makes a very similar point in a poem entitled 'Freedom's Dawn (August 1947)'

This leprous daybreak, dawn night's fangs have mangled-

This is not that long-looked-for break of day,

Not that clear dawn in quest of which those comrades

Set out, believing that in heaven's wide void

Somewhere must be the stars' last halting-place

Somewhere the verge of night's slow-washing tide,

Somewhere an anchorage for the ship of heartache. (Faiz 123-125) 
By comparing the journey of the displaced to the journey of the struggle for independence, Faiz is able to highlight not the state-endorsed euphoria of independence, but the disillusionment of promises broken —of the realization that the reality has not matched up to its expectation. Achintya Kumar Sengupta makes this point even more explicitly:

\author{
Who are those travelling with us - Who? \\ They too are refugees. \\ They have suffered, been imprisoned \\ They have crossed violent peaks and suffering seas \\ ... \\ Till tired at the end of the chapter \\ Looking at the torn broken tattered map \\ They suddenly see a dazzling heaven's call \\ And they run breathless \\ To be paid for all their work \\ Yes, they too are refugees \\ Some from their homes \\ Others from their ideals. (Sengupta 12-13)
}

Faiz and Sengupta are both making a causal link between the seeming despair of the refugees' journey and the fact that the metaphorical national journey to independence went wrong and, thus, in the process, they are able to use the figure of the refugee and the melancholic longing of their homeland to highlight the dissatisfaction with the new independent, but partitioned nations. Indeed, it is the very fact of the refugees' transience that stands as the marker of failure of independence.

An enduring symbol of melancholic transience is the train. Train journeys and railway stations feature prominently throughout all forms of cultural production of the Partition. From novels like Khushwant Singh's Train to Pakistan and John Masters' Bhowani Junction to photographs of Margaret Bourke-White, to numerous short stories, films such as Ritwik Ghatak's Komal Gandhar and Deepa Mehta's Earth - it seems that railways and train journeys are all-pervasive in Partition narratives. This might be partly because seemingly naturalised orderliness which is associated with railways as signifiers of stable, modern secular public life becomes the perfect contrast to depict the chaos of Partition. The refugee family from Achintya Kumar Sengupta's poem, too, travels from their old home to the new by train:

Travelling almost to the horizon

By boat from here to the pier

From there to the railway station.

What fun - your first train journey today

All the way to the checkpost

From there —walking walking walking. (Sengupta 9) 
Even when journeys aren't being documented — trains and stations feature prominently as transitional spaces full of rootless people. A case in point is Sujata Bhatt's poem called 'Partition':

She was nineteen-years-old then and when she stood in her garden she could hear the cries of the people stranded in the Ahmedabad railway station. She felt it was endless - their noise - a new sound added to the city. (Bhatt 34)

The melancholy of exile is contrasted with a deeply nostalgic longing for the lost homeland. In her analysis of Debjani Sengupta's anthology of Bengali partition stories, Terry Tomsky identifies this characteristic feature of Partition narratives:

... a melancholic and exilic longing for the 'lost' other. It suggests that the other Bengal continues to function as an imaginary homeland, an affective site of desire, loss, and unattainability that haunts the East Bengali migrant generations. (67)

Achintya Kumar Sengupta's 'Refugee' is, once again, a case in point:

Green trees next to the shadow kissed pond

Birds wake up and sing familiar notes

The little boy looks out of the window

And sees his kite dangling from the tree

Buffeted by the wind but not letting go

The moss on the river banks

Looks sadly back — where will you go?

...

Further, the gurgling burbling river

Asking, where will you go without us?

Are we friends from an earlier life?

No one in this? No one dear? (Sengupta 10)

The deliberate poignancy of describing the pastoral idyll that has been left behind as being full of 'friends from an earlier life' highlights both the strong affective relationship with the landscape (which is now apparently that of a foreign, othered country, and demonstrates the trauma of the process through which access to that past homeland has now been lost. The anthropomorphizing of the landscape highlights vividly the trauma of the moment of parting, as well as reinforcing an apparent contrast between the timeless stasis of rural life and the pathologised, modern industrial forms of transport which is allowing the refugees to leave their home.

Sindhi poet Prabhu Wafa, in a poem called 'Shadow Play' also recreates an image of an idyllic, pre-lapsarian vision of the homeland:

Those were happy days...

Homes, fields, cattle, fodder,

Gardens in full bloom,

Peace, prosperity, God's blessings. (Wafa 2010) 
Sujata Bhatt, in her poem, contrasts the railway station as the symbol of the trauma of Partition, with the image of a garden as the symbol of pre-Partition paradise:

Her aunt, her father's sister, would go to the station every day with food and water - But she felt afraid, felt she could not go with her aunt- So she stood in the garden listening. (Bhatt 34)

I have written elsewhere (Raychaudhuri 474-475) about the importance of the pastoral in Bengali cinema of Partition and, similar to my readings of the works of cinematic auteur Ritwik Ghatak, it should be borne in mind here as well that this vision of a pastoral idyll is no simplistic anti-modern, anti-industrial and antiwestern call to return to a more simplistic, imaginary pastoral life. What is being stressed here is the potentially powerful affective relationship between humanity and nature that can transcend the nationalistic differences that are, according to this argument, leading to the violence of Partition. In another poem called 'East-West', Achintya Kumar Sengupta makes this transnational power of the pastoral apparent:

Your Sitallakkha and my Mayurakkhi

Your Bhairab and my Rupnarayan

Your Karnaphuli and my Shilaboti

Your Payra and my Piyali

One water one wave one stream

One cool bottomless deep of prosperous peace.

The sunlight in your eyes warms my yard

The wind in your heart touches the flowers in my garden (Sengupta 1)

The litany of river-names with which Achintya Kumar Sengupta begins this poem reflects the unifying potential that the poet feels is contained within the natural landscape. Similarly, Amrita Pritam, in 'The Bridge' imagines a riverscape as the antidote to what she sees as artificial divisions of the land:

Yesterday you and I

Burnt a bridge

And divided our destinies

Like the two banks of a river.

...

Before we fade away

Standing thus apart from each other

Let us spread our lean bodies

On the surface of the waters

And you step on your own body

To span half the river

While I will tread on my body

And will receive you more than halfway. (Pritam 37) 
What seems to be common in both Pritam and Sengupta is that the evocation of an organic relationship between humanity and nature can be used as an antidote to the alienation that has been caused by the uprooting of people. In depicting oneself and one's people as autochthonous, one can challenge Partition as not just counter-intuitive and unnatural, but also challenge the hegemony of the new post-colonial nation state as necessarily inclusive of, and able to represent these uprooted people. When the nation-state is busy appropriating and silencing painful history in favour of a coercive, absolutist celebration of independence, these nostalgic yearnings for what has been lost, spaces that have now been hegemonically othered as part of another, enemy country, remain important as counter-normative melancholic positions.

It is perhaps too easy to scoff at such nostalgic recreation of an imaginary homeland, and nostalgia, in general, has been strongly attacked by most theorists. Writing in a different context, Susan Bennett, for example, has forcefully argued that nostalgia's 'representation of a seamless past has ... been an important strategy in the politically regressive governments of the New Right ... In all its manifestations, nostalgia is, in its praxis, conservative' (Bennett 4-5). Similarly, Svetlana Boym has described nostalgia as 'an abdication of personal responsibility, a guilt-free homecoming, an ethical and aesthetic failure.' (Boym xIV) What most of these views on nostalgia share, then, is a criticism of what David Lowenthal has called nostalgia's 'search for a simple and stable past as a refuge from a turbulent and chaotic present.' For most of these critics, nostalgia represents a need to return to politically-regressive Modernist grand-narratives. (Lowenthal 21)

I do not deny that the nostalgic re-creation of a complex, contradictory, hierarchical past into a simple, palatable and stable version is problematic. Nostalgia can and has been used to reinforce particularly reactionary political forces and, as such, is, at best, a very ambiguous force. I do argue, however, that when in contact with the colonialist or even the postcolonial state, the marginalized and displaced subject can and does use nostalgia as a particularly radical force to articulate radical notions of identity and belonging.

It is particularly interesting how Faiz Ahmed Faiz uses a poetic tradition of nostalgic and melancholic love poetry to articulate particularly radical notions. V.G. Kiernan has pointed out how

Faiz began with the stereotype of the cruel beauty ... though still only elusively suggested by comparison with Western love-poetry, and ... in some manner was able to fuse sympathy for the hard-pressed labourer or peasant with the traditional griefs of the lover ... In like fashion wine may stand now for political truth or insight instead of spiritual, madness for the enthusiast's self-sacrifice in a progressive cause. (Faiz 39)

The addressee in Faiz's poetry then is not just the target of unrequited melancholic love as in the tradition he is working from, but for Faiz this 'you' comes to mean many things - the oppressed subject, the revolutionary idealist and, also, the pre-Partition homeland. This may facilitate a fuller reading of some of Faiz's most melancholic poems, for example: 
Do not ask how much I have longed for you

Since those lost days of longing expectation;

Your image fills these unfamiliar springs

That are not your embrace, your arms, your lips. (Faiz 133)

A similar use of melancholic love poetry can be seen in Amrita Pritam's poems - in particular in perhaps her most famous poem of Partition, where she invokes the name of Waris Shah, an 18th-century Punjabi Sufi poet, most famous for the epic poem of tragic love, Heer Ranjha:

To Waris Shah I turn today!

'Speak up from the graves midst which you lie!

In our book of love, turn the next leaf.

When one daughter of the Punjab did cry

You filled pages with songs of lamentation,

Today a hundred daughters cry

O Waris to speak to you.'

Waris Shah!

Open your grave;

Write a new page

In the book of love. (Pritam 93-94)

Like Faiz, Pritam is able to use the radical uncertainty about the nature of the addressee in other poems as well, most notably 'At Midnight' and 'The Bridge', both discussed above. Faiz and Pritam are both able to use tropes of poetic convention in order to articulate radical new sentiments. In one poem, for example, the 'you' that is the object of powerful, often unrequited and lost love is fused with the figure of Lenin, as Pritam writes:

For history's perfection

I imprisoned you in the calendar

Again and again;

Stamped it with the national era;

Stuck several nails of isms:

They were futile imprisonments.

Out from my wall calendar,

Changing the dates again

You meet me like a new day;

With new frustrations, new salvations. (Pritam 145)

Like Faiz, who Kiernan describes as 'a socialist with a groundwork of Muslim culture and feeling' (Faiz 40), Pritam, too, is able to borrow from different, often conflicting and contradictory influences of tradition, in order to articulate new and oppositional ideas. In an interview with Carlo Coppolla for Mehfil in 1968, Pritam expands on the oppositional nature of her politics: 
I wouldn't call myself a Marxist. I am too much of an individualist to be one. I can admire something when it's good for the welfare of the people. Of course, I admire Marxism ... I can't label myself that easily, though there are some qualities in Marxism that I admire. I have visited Soviet Russia several times, three in fact, and other socialist countries as well. I admire some of the changes there, but not all, especially the lack of individual freedom. I have spoken freely about that there. (Coppolla and Pritam 7)

If the addressee of the poems is often out of reach then the pastoral idyll which the addressee symbolizes is also often horrifically altered by the horrors of Partition:

Men's bodies sold in street and marketplace,

Bodies that caked grime fouls and thick blood smears,

Flesh issuing from the cauldrons of disease

With festered sores dripping corruption - these

Sights haunt me too, and will not be shut out;

Not be shut out, though your looks ravish still. (Faiz 67)

Similarly, the garden in Sujata Bhatt's poem does not provide an escape from the trauma either:

Even the birds sounded different — and the shadows cast by the neem trees brought no consolation. And each day she wished she had the courage to go with her aunt- (Bhatt 34)

The idyll of pre-Partition Punjab is spoiled by violence in Amrita Pritam's poetry as well:

O friend of the sorrowing, rise and see your Punjab

Corpses are strewn on the pasture,

Blood runs in the Chenab.

Some hand hath mixed poison in our five rivers

The rivers in turn had irrigated the land.

From the rich land have sprouted venomous weeds

How high the red has spread

How much the curse has bled! (Pritam 93)

Similarly, the paradise evoked by Prabhu Wafa existed only in his prePartition imagination. After Partition, the world has changed forever:

A leaf here,

A leaf there, families rootless,

homes plundered.

Through the desert, in caravans, we departed

treading thorny paths. (Wafa 2010) 
The nostalgic memories of the lost homeland and the melancholic engagement with the experience of exile together allow these poets to cross the inter-space between the nation-states. As exiles writing about exile, they occupy the spaces in the margins between the two nation-states. Bengali poet Subhash Mukhopadhyay, in a short poem called 'Crossings' provides a perfect example:

We are like the pupils of Bangladesh's two eyes,

Whoever polices the border, or tries.

The door is blocked, so we've pulled open the window

The Bangladesh on the other side is the same Bangla on this. (Mukhopadhyay 44)

The particular radical nature of this poem is encompassed in the use of the word 'Bangladesh' - this poem was written before the establishment of the nation-state as it exists today. Bangladesh in this context refers to undivided Bengal. A moment needs to be spared for the Bengali word "desh," which although almost always translated as "country" is actually more complex than that. Bengalis use the word "desh" to mean nation (as in India), territory (as in West Bengal), and, especially significant for migrant populations, the original home, village or town where the family had to move from for economic or political reasons. The deliberate vagueness with which poets like Subash Mukhopadhyay uses the word means that the characters could be referring to any or, indeed, all of these ideas. This vagueness is enormously radical as it implicitly highlights the gaps between displaced people's emotional attachments and allegiances to the landscape they have left behind, and the political boundaries of the nation-state.

This is perhaps the most important way in which nostalgia and melancholia is mobilized in these poems for particularly radical ends - the affect of nostalgic melancholy is used to transcend the national borders and establish links across the borders. Thus, these poets are challenging the most persistent myth of the postcolonial nation building - that Partition led to the establishment of independent, homogenous, unified nations who are mirror-images of each other, and can therefore unproblematically construct their identity in opposition to the other across the border. Nostalgic melancholia, in this instance, not only involves 'an ongoing and open relationship with the past — bringing its ghosts and specters, its flaring and fleeting images into the present' in the words of Eng and Kazanjian (4), but it brings into the present exactly those ghosts that the postcolonial states of today would rather remain safely buried. By refusing to mourn, by insisting on melancholia instead, the poets I have studied here are also rejecting the state-endorsed narrative that these horrors can be safely relegated into the dustbins of history. 


\section{REFERENCES}

Benjamin, Walter. Illuminations. Ed. Hannah Arendt. Pimlico, 1999.

Bennett, Susan. Performing Nostalgia: Shifting Shakespeare and the Contemporary Past. Routledge, 1996.

Bhatт, Sujata. Augatora. Carcanet, 2000.

Boym, Svetlana. The Future of Nostalgia. Basic Books, 2001.

Butalia, Urvashi. The Other Side of Silence: Voices from the Partition of India. Penguin, 1998.

Cleary, Joe. Literature, Partition and the Nation-State: Culture and Conflict in Ireland, Israel, and Palestine. Cambridge University Press, 2002.

Coppolla, Carlo and Amrita Pritam, 'Carlo Coppolla Interviews Amrita Pritam' in Mahfil, 5:3 (1968), pp. 5-26.

Darya, Kavita. Violent Belongings: Partition, Gender, and National Culture in Postcolonial India. Temple University Press, 2008.

Didur, Jill. Unsettling Partition: Literature, Gender, Memory. University of Toronto Press, 2006.

Eng, David and David Kazanjian eds. Loss: The Politics of Mourning. University of California Press, 2003.

Faiz, Faiz Ahmed. Poems by Faiz Trans. and Ed. V.G. Kiernan. Oxford University Press, 2009.

Freud, Sigmund. On Murder, Mourning and Melancholia. Trans. Shaun Whiteside. Penguin, 2005.

Kabir, Ananya. 'Gender, Memory, Trauma: Women's Novels on the Partition of India' in Comparative Studies of South Asia, Africa, and the Middle-East, 25:1 (2005), pp. 177-90.

Khanna, Ranjana. Dark Continents: Psychoanalysis and Colonialism. Duke University Press, 2003.

'Post-Palliative: Coloniality's Affective Dissonance' in Postcolonial Text, 2:1 (2006), http:// postcolonial.org/index.php/pct/article/viewArticle/385/815. Accessed 25 September 2012.

Lowenthal, David. "Nostalgia Tells it Like it Wasn't." The Imagined Past: History and Nostalgia. Ed. Malcolm Chase and Christopher Shaw. Manchester University Press, 1989, pp. 18-32.

Masters, John. Bhowani Junction Penguin, 1960.

Menon, Ritu and Kamla Bhasin. Borders and Boundaries: Women in India's Partition. Rutgers University Press, 1998.

Moon, Penderel. Divide and Quit: An Eyewitness Account of the Partition of India. University of California Press, 1962.

Mukhopadhyay, Subhash. Subhas Mukhopadhyay er Shrestha Kobita. Dey’s Publishing, 2004.

Nehru, Jawaharlal. Jawaharlal Nehru's Speeches, Volume 1 Sep 1946-May 1949. Ministry of information and Broadcasting, Government of India, 1958.

Pandey, Gyanendra. Remembering Partition. Cambridge University Press, 2001.

Pritam, Amrita. Selected Poems. Ed. Khushwant Singh. Bharatiya Jnanpith, 1982.

Raychaudhuri, Anindya. 'Resisting the Resistible: Re-writing Myths of Partition in the Works of Ritwik Ghatak.' Social Semiotics 19:4 (2009), pp. 469-481.

Sengupta, Achintya Kumar. Pub-Pashchim. Anandadhara Prakashan, 1970.

Sengupta, Debjani, ed. Mapmaking: Partition Stories from 2 Bengals. Srishti, 2003. 
Singh, Khushwant. Train to Pakistan. Penguin Viking, 2007.

Tацвот, Ian. "The 1947 Partition of India" in The Historiography of Genocide. Ed. Dan Stone. Palgrave Macmillan, 2008, pp. 420-437.

Tomsky, Terri. 'Fifty Years On: Melancholic (Re)collections and Women's Voices from the Partition of India' in Life Writing, 5:1 (2008), pp. 61-78.

Wafa, Prabhu. 'Shadow Play' in English Translations of Some Poetry on Sindhi Partition, 2010. http:// prabhuwafa.com. Accessed 25 September 2012. 
